\title{
Improved ceramic anodes for SOFCs with modified electrode/electrolyte interface
}

Stamate, Eugen; Abdul Jabbar, Mohammed Hussain; Høgh, Jens Valdemar Thorvald; Zhang, Wei; Thydén, Karl Tor Sune; Bonanos, Nikolaos

Publication date:

2014

Link back to DTU Orbit

Citation (APA):

Stamate, E., Abdul Jabbar, M. H., Høgh, J. V. T., Zhang, W., Thydén, K. T. S., \& Bonanos, N. (2014). Improved ceramic anodes for SOFCs with modified electrode/electrolyte interface. Abstract from 2nd International Workshop on Solution Plasma and Molecular Technologies, Goyang City, Korea, Republic of.

\section{General rights}

Copyright and moral rights for the publications made accessible in the public portal are retained by the authors and/or other copyright owners and it is a condition of accessing publications that users recognise and abide by the legal requirements associated with these rights.

- Users may download and print one copy of any publication from the public portal for the purpose of private study or research.

- You may not further distribute the material or use it for any profit-making activity or commercial gain

- You may freely distribute the URL identifying the publication in the public portal 


\title{
Improved ceramic anodes for SOFCs with modified
}

\author{
electrode/electrolyte interface
}

\author{
E. Stamate $^{1}$, A. J. Mohammed Hussain ${ }^{1,2}$, J.V.T. Høng ${ }^{1}$, W. Zhang ${ }^{1}$, \\ K.T.S. Thyden ${ }^{1}$ and N. Bonanos ${ }^{1}$ \\ ${ }^{1}$ Department of Energy Conversion and Storage, Technical University of Denmark, \\ Frederiksborgvej 399, Roskilde 4000, Denmark \\ ${ }^{2}$ University of Maryland Energy Research Centre, University of Maryland, \\ College Park, Maryland 20742-2115, USA \\ E-mail: eust@dtu.dk
}

Conventional anodes for solid oxide fuel cells (SOFCs) consist of a cermet of nickel and yttrium-stabilized zirconia (YSZ). Although NieYSZ cermet has excellent electrochemical properties for hydrogen oxidation, it has the drawback of high polarization resistance at low temperatures and poor redox stability. High performing alternative anodes are required to overcome the limitations of NieYSZ cermets for low temperature SOFC (LTSOFC) applications. Recently, ceramic based materials have been extensively studied for LT-SOFCs, e.g. Sr0.94Ti0.9Nb0.1O3 (STN) perovskite type oxides. In spite of their low oxide ion conductivity and poor catalytic activity for hydrogen oxidation, these oxides have excellent electronic conductivity and redox stability. Various attempts have been made to use doped-SrTiO3 as a potential LT-SOFC anode. While composites of STN/YSZ would probably provide the necessary oxide ion transport; these cannot be used for SOFC anodes without further modification, due to their high polarization resistances. When pure electronic material like STN is used as anode, the electrochemical reactions are confined to the electrode/electrolyte interfaces (EEI), where electrode, electrolyte and the fuel gas are in contact forming a three phase boundary (TPB). Incorporation of nanostructured, catalytically active sites and path for oxide ion conduction is necessary in extending the TPBs. TPB length plays a crucial role in improving the performance of SOFC anodes. Moreover, introducing electrocatalyst such as $\mathrm{Ni}$ and Gd-doped ceria (CGO) by infiltration is proven to extend the TPB length and to improve the performances. The main goal of this study is to improve the performance of STN based anodes by introducing catalyst nanoparticles at the EEI i.e., nanosized Pd catalyst was incorporated in the required site of hydrogen oxidation in the form of a metal functional layer (MFL). The study was made systematic by varying the thickness of MFL deposited at the interface with the aim to increase the loading of catalyst; however the best performance is achieved with a MFL of 20 and $30 \mathrm{~nm}$. The combined beneficial effects of PdeCGO electrocatalyst infiltration and distributed Pd nanoparticles at the interface have shown a drastic improvement in electrode performance at low temperatures [1].

[1] A. J. Mohammed Hussain, J.V.T. Høng, W. Zhang, E. Stamate, K.T.S. Thyden and N. Bonanos, J. Power Sources, 212 (2012) 247. 